\title{
Canadian charged with smuggling Ebola
}

The arrest at a US border of a researcher allegedly trying to smuggle non-infectious Ebola DNA in from Canada is raising questions about high-containment lab security.

But officials on both sides of the border are saying little about how the samples were removed from the Canadian National Microbiology Laboratory in Winnipeg, or about the suspect, 42-year-old Konan Michel Yao, who was a fellow at the laboratory until January.

On 5 May, Yao was discovered to have 22 vials of Ebola genetic vectors as he tried to drive into North Dakota. He was charged three days later with smuggling biological material and making false statements to authorities. The incident became public only last week.

Yao, now a Canadian citizen but born in Ivory Coast, told US agents that he was heading to a fellowship at the National Institutes of Health (NIH) in Bethesda, Maryland, and had documents indicating this to be the case, court records say.

An NIH spokeswoman refused to discuss the case. Canadian government officials didn't respond to an inquiry.

\section{New York's health commissioner to head CDC}

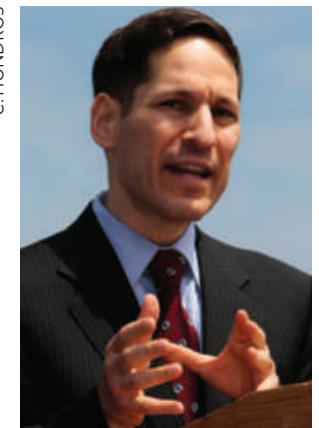

Thomas Frieden.
Thomas Frieden, New York City's health commissioner, has been appointed head of the US Centers for Disease Control and Prevention (CDC) in Atlanta, Georgia.

Frieden worked for the agency from 1990 to

2002, when his work included tackling the spread of multidrug-resistant tuberculosis in India. In New York, he has worked to reduce tobacco use and to develop emergency-response plans in case of a pandemic. Back at the $\mathrm{CDC}$, he will take over an agency on the front lines of battling the H1N1 swine-associated influenza outbreak.

During the 1990s, Frieden worked for another New York health commissioner: Margaret Hamburg, who on 18 May received Senate confirmation to head the US Food and Drug Administration.

Frieden's appointment does not require Senate confirmation.

\section{Astronauts complete Hubble repairs}

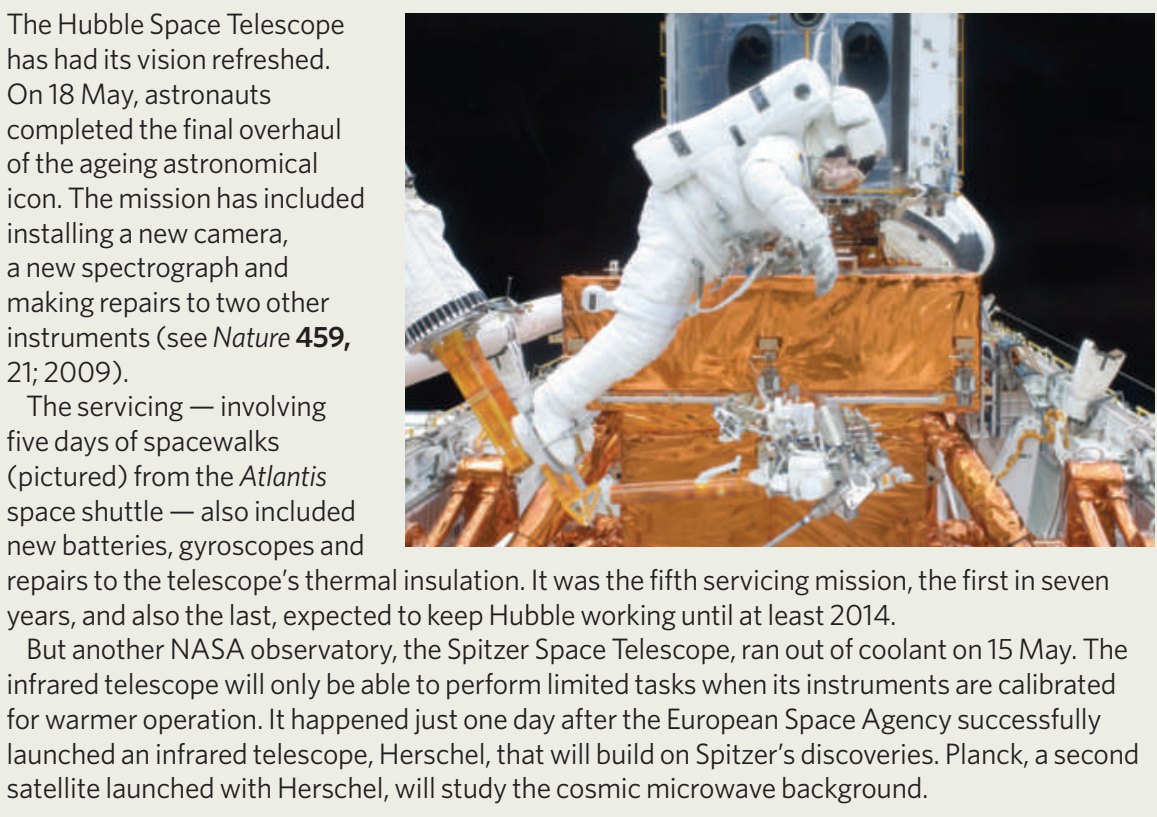

\section{Lawsuit targets validity of human-gene patents}

In a case that could determine the fate of gene patents, a group of cancer patients, clinicians, researchers and activists have sued the US Patent and Trademark Office and the owners of patents on two genes associated with cancer.

The lawsuit, filed on 12 May, targets Myriad Genetics and the University of Utah Research Foundation, both based in Salt Lake City, and both of which own patents on the BRCA1 and BRCA2 genes. Certain mutations in these genes have been linked to an increased risk of breast and ovarian cancer but, because Myriad Genetics holds exclusive rights, diagnostic testing for these mutations can only be performed at Myriad labs.

The lawsuit asserts that patents on human genes associated with breast and ovarian cancer are invalid and that they violate the US constitution. The lawsuit "does have a lot of potential”, says Arti Rai, a law professor at Duke University in Durham, North Carolina. "But it's still a hard case to make."

\section{Re-election of Indian prime minister aids nuclear deal}

A nuclear trade deal struck last year between India and the United States remains on course to be implemented, after the ruling left-of-centre United Progressive Alliance (UPA) secured an unexpectedly decisive victory in India's elections.

Opposition parties had vowed to review the deal if they came to power, arguing it would reduce the independence of
India's domestic nuclear programme.

Aside from nuclear policy, the contesting parties broadly agreed on scientific issues. But the continuity assured by the election of prime minister Manmohan Singh to a second term in office means that the science agenda can move forwards without disruption, says Rajagopala Chidambaram, principal science adviser to the government.

The UPA has committed to raise government spending on science from $0.9 \%$ of gross domestic product to $2 \%$ by 2012 .

For a longer version of this story, see http://tinyurl.com/q6cggs.

\section{Austrian scientists celebrate CERN U-turn}

Austria has reversed its decision to withdraw from CERN, Europe's particle-physics laboratory near Geneva in Switzerland.

On 8 May, science minister Johannes Hahn had announced that Austria would end its participation in 2010. Instead, the country would use its annual contribution of about $€ 17$ million (US $\$ 23$ million) to make up shortfalls in the country's research budget. The decision sent shock waves through the country's physics community (see Nature 459, 151; 2009).

Protests were not in vain. On 18 May, Chancellor Werner Faymann overruled his science minister and announced that Austria would continue its 50-year-old membership in CERN without cuts.

"Austrian science as a whole will benefit from this firm declaration of belief in basic research," says Christian Fabjan, director of the Austrian Academy of Sciences' Institute for High Energy Physics in Vienna. 